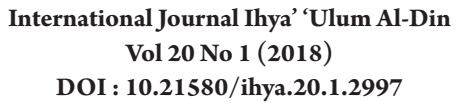

\title{
Kearifan Lokal di Pedesaan: Kajian Praktik Budaya Religi di Desa Nyatnyono
}

\author{
Mila Sartika \\ Universitas Dian Nuswantoro Semarang Jawa Tengah \\ E-mail:mila.sartika@dsn.dinus.ac.id \\ Hendri Hermawan Adinugraha \\ Universitas Dian Nuswantoro Semarang Jawa Tengah \\ E-mail: hendri.hermawan@dsn.dinus.ac.id \\ Hayu Wikan Kinasih \\ Universitas Dian Nuswantoro Semarang Jawa Tengah \\ E-mail:hayu.wikan.kinasih@dsn.dinus.ac.id
}

\begin{abstract}
One element of culture in Javanese society is belief or religion. Religion has two meanings: First, religion is a religion related to God, its teachings are revealed through prophets and revelations. The truth is absolutely inviolable based on the beliefs of the adherents. Second, religion are part of culture, to fulfill collective awareness and identity. Therefore, every society has a certain way and is different from one region to another in carrying out their beliefs. Nyatnyono village, for example, they have a firm belief held in the form of a ritual carried out on certain days inherited from their ancestors. In the context of this research, religion is not only a religion but also as a cultural phenomenon as well as local wisdom which is full of values practiced by its people. Based on this explanation, this study aims to describe religious culture as a form of local wisdom in the village of Nyatnyono in Semarang Regency. This research is a descriptive qualitative type of research. The results of this study indicate that there are many religious cultures that have been adopted into local wisdom for the people of Nyatnyono Village such as the iriban tradition, merti dusun, yasinan, nyadran (ruwahan), pengajian nuzul al-Qur'än, syuronan, tirakatan, and so on. However, the tradition or habit that dominates in the village of Nyatnyono is the ziyarah of the tomb of Mbah $\mathrm{H}$ asan Munadi and Mbah Hasan Dipuro and Mandi at Sendang Kalimah T. ayyibah and Sendang Amanah, where it has been a hereditary culture for the
\end{abstract}


Nyatnyono Village and those cultures that deliver Nyatnyono Village as one of the religious tourism icons in Semarang Regency with visitors from various regions so as to create jobs for the local community and be able to increase the Regional Revenue of Semarang Regency.

Keywords: Local wisdom, religious culture and Nyatnyono village.

\begin{abstract}
ABSTRAK
Salah satu unsur kebudayaan di masyarakat Jawa adalah keyakinan atau religi. Religi mempunyai dua makna: Pertama, religi merupakan agama yang berkaitan dengan Tuhan, ajarannya diturunkan melalui nabi dan wahyu. Kebenarannya mutlak tidak bisa di ganggu gugat berdasarkan keyakinan penganutnya. Kedua, religi merupakan bagian dari kebudayaan, untuk memenuhi kesadaran kolektif dan sebagai identitas. Karena itu, setiap masyarakat memiliki cara tertentu dan berbeda antara satu daerah dengan daerah lainnya dalam menjalankan keyakinannya. Desa Nyatnyono, misalnya, mereka memiliki kepercayaan yang dipegang teguh dalam bentuk ritual yang dilaksanakan pada hari-hari tertentu yang diwariskan oleh nenek moyangnya. Dalam konteks penelitian ini, religi tidak saja sebagai agama saja tetapi juga sebagai fenomena kultural sekaligus kearifan lokal yang sarat dengan nilai yang dipraktikkan oleh masyarakatnya. Berdasarkan paparan tersebut penelitian ini bertujuan untuk untuk mendeskripsikan budaya religi sebagai bentuk kearifan lokal masyarakat di Desa Nyatnyono di Kabupaten Semarang. Penelitian ini merupakan jenis penelitian kualitatif yang bersifat deskriptif. Hasil penelitian ini menunjukkan bahwa terdapat banyak budaya religi yang sudah diadopsi menjadi kearifan lokal bagi masyarakat Desa Nyatnyono seperti tradisi iriban, merti dusun, yasinan, nyadran (ruwahan), pengajian nuzul al-Qur'ān, syuronan, tirakatan, dan lain sebagainya. Akan tetapi tradisi atau kebiasaan yang mendominasi di Desa Nyatnyono ialah ziyarah makam Mbah Hasan Munadi dan Mbah Hasan Dipuro, serta Mandi di Sendang Kalimah Țayyibah dan Sendang Amanah, di mana hal tersebut sudah menjadi budaya turun temurun bagi masyarakat Desa Nyatnyono dan budaya-budaya tersebut yang menghantarkan Desa Nyatnyono sebagai salah satu ikon wisata religi di Kabupaten Semarang dengan pengunjung yang berasal berbagai daerah sehingga dapat menciptakan lapangan pekerjaan bagi masyarakat lokal dan mampu menambah Pendapatan Asli Daerah (PAD) Kabupaten Semarang.
\end{abstract}

Kata Kunci: Kearifan lokal, budaya religi, dan Desa Nyatnyono. 


\section{Pendahuluan}

Keragaman budaya dan suku bangsa kita menjadi daya tarik bagi dunia untuk berkunjung ke Indonesia. Keragaman budaya dan suku tersebut menjadi keunikan serta kekuatan bangsa kita. Ia dipertahankan dan berlangsung dari generasi ke generasi dan menjadi identitas bangsa dan negara Indonesia.

Budaya bangsa Indonesia diletakkan sebagai sebuah kearifan karena dilandasi oleh nilai, norma, sikap, dan prilaku yang luhur. Bagi masyarakat muslim, nilai, norma, sikap, dan perilaku luhur yang melandasi budaya mereka tentu tidak dapat dilepaskan dari nilai, prinsip, dan norma ajaran Islam yang mereka anut.

Sejarah membuktikan bahwa budaya di Jawa tidak bisa dilepaskan dari norma serta nilai ajaran Islām, dan kesadaran masyarakat Jawa sebagai makhluk pribadi dan sosial juga dapat dilihat dari moral etisnya (Deni Adi Wijaya, Djono, and Ediyono 2018, 116). Misalnya, pada periode Abed ke- 14 dan 16, Islām membawa beberapa perubahan penting dalam kehidupan beragama. Tetapi orang-orang muslim Jawa di pesisir menjadi lebih legalistik daripada orang-orang di pedalaman karena yang pertama mengalami lebih banyak kontak dengan dunia luar, termasuk para penceramah yang berorientasi pada syarīah, sementara yang terakhir telah akrab dengan peradaban Hindu-Budha. Di pedalaman, subjek kemungkinan besar menjadi muslim karena junjungan mereka. Pada abad ke-16 ajaran sufi (mistis) telah dikenal di mana Islām menjadi sumber energi supernatural. Sebuah babad Jawa, Babad Tanah Jawi, misalnya, mengatakan: "Pada waktu itu banyak orang Jawa ingin diajari agama Nabi (Islām) dan belajar kekuatan supernatural dan tak terkalahkan." Jadi, pada periode ini, sinkretisme menjadi lebih dominan di pedalaman daripada di pesisir Jawa (Muhammad Ali 2011, 10-11).

Dominasi sosial orang Jawa adalah ciri masyarakat Indonesia. Masyarakat Jawa, bersama dengan budaya dan tradisinya, mendominasi sebagian besar masyarakat Indonesia pada umumnya. Hegemoni budaya Jawa dalam masyarakat Indonesia terjadi karena dukungan politik, sistem pendidikan formal, dan media. Nilai-nilai, pandangan dan gaya hidup masyarakat Jawa telah menjadi sumber dan acuan standar bagi 
banyak cita-cita dan nilai-nilai masyarakat Indonesia saat ini (Maula 2016, 112).

Berdasarkan realita tersebut, maka salah satu unsur kebudayaan yang ada di masyarakat Jawa adalah keyakinan atau religi. Religi mempunyai dua makna: Pertama, religi merupakan agama yang berkaitan dengan Tuhan, ajarannya diturunkan melalui nabi dan wahyu. Kebenarannya mutlak tidak bisa di ganggu gugat berdasarkan keyakinan penganutnya. Kedua religi merupakan bagian dari kebudayaan untuk memenuhi kesadaran kolektif dan sebagai identitas (Hariyanto 2016, 217).

Setiap masyarakat memiliki cara tertentu dan berbeda antara satu daerah dengan daerah lainnya dalam menjalankan keyakinannya. Demikian juga dengan masyarakat di desa Nyatnyono yang masih memiliki kepercayaan warisan dari nenek moyang yang masih dipegang teguh hingga saat ini dimana kepercayaan ini adalah berupa ritual yang dilaksanakan pada hari-hari tertentu.

Dalam tulisan ini, religi tidak dimaknai hanya sekedar sebagai agama, tetapi juga sebagai fenomena kultural, khususnya budaya religi di Desa Nyatnyono yang dinilai sebagai kearifan lokal tanah Jawa yang sarat dengan makna dan senantiasa dipraktikkan oleh masyarakatnya (Rini Fidiyani and Baidhowi 2015, 282).

Berdasarkan paparan di atas, penelitian ini berupaya untuk mendeskripsikan budaya religi sebagai bentuk kearifan lokal masyarakat di Desa Nyatnyono Kabupaten Semarang.

Penelitian ini adalah penelitian kualitatif dengan menggunakan kekuatan pancaindra untuk mendeskripsikan fenomena budaya. Kekuatan pancaindra digunakan untuk melihat kecenderungan perubahan budaya seiring dengan perubahan zaman.

Penelitian kualitatif memposisikan peneliti sebagai pengumpul data, mengikuti asumsi kultural dan mengikuti data. Karena itu, penelitian budaya yang bersifat kualitatif ini lebih fleksibel tidak memberi harga mati, reflektif, dan imajinatif (Endraswara 2003, 16).

Pemilihan pendekatan kualitatif dengan metode studi kasus pada penelitian ini, didasarkan pada adanya tujuan untuk memperoleh 
deskripsi secara utuh dan realistis mengenai budaya religi yang diimplementasikan sebagai kearifan lokal di Desa Nyatnyono.

Sumber data yang digunakan adalah data primer dan sekunder. Teknik pengumpulan datanya dilakukan dengan observasi, wawancara, dan studi kepustakaan.

Penelitian dilakukan di Desa Nyatnyono, Kecamatan Ungaran Barat, Kabupaten Semarang. Penelitian ini difokuskan pada budaya-budaya religi yang dijadikan sebagai kearifan lokal di Desa Nyatnyono

\section{Letak Geografis Desa Nyatnyono}

Desa Nyatnyono berada di Kecamatan Ungaran Barat, Kabupaten Semarang, Provinsi Jawa Tengah. Secara Geografis Desa Nyatnyono Kecamatan Ungaran Barat Kabupaten Semarang terletak di lereng Gunung Ungaran atau sebelah Barat Kota Ungaran, dengan ketinggian berkisar 600-800 meter di atas permukaan laut dengan suhu udara rata-rata $240-280 \mathrm{C}$. Tipologi tanahnya berbukit sedang dan sebagian berupa dataran. Disamping itu keadaan tanahnya merupakan tanah yang sebagian besar untuk kegiatan pertanian dan sisanya untuk tanaman budidaya. Desa Nyatnyono merupakan Desa yang cukup subur. Kesuburan ini, terutama karena sifat tanahnya yang berhumus, berupa bebatuan, serta didukung ketersediaan air yang cukup. Potensi ini yang akhirnya menghijaukan daerah atau wilayah desa Nyatnyono dan wilayah desa sekitarnya. Batas wilayah desa Nyatnyono, sebelah utara berbatasan dengan desa Lerep, sebelah timur berbatasan dengan kelurahan Genuk, sebelah barat berbatasan dengan PTP Sebigo, dan sebelah selatan berbatasan dengan desa Gogik (Nyatnyono 2014).

Luas desa Nyatnyono + $425 \mathrm{Ha}$ yang terdiri dari tanah sawah ladang 15.5 Ha, tanah untuk pemukiman $67 \mathrm{Ha}$, tanah tegalan $6.5 \mathrm{Ha}$, bangunan umum 7.4 Ha, jalan, makam sekitar $28 \mathrm{Ha}$, dan lain-lain $63 \mathrm{Ha}$. Ditinjau dari segi demografis, Desa Nyatnyono dibagi menjadi 8 dusun (Gelap, Gundang, Krajan, Siroto, Sendang Putri, Sendang Rejo, Blanten), 8 Rukun Warga, dan 35 Rukun Tetangga (Nyatnyono 2014). 


\section{Sejarah Desa Nyatnyono}

Bermula dari kerajaan Islām pertama di Jawa yakni kerajaan Demak yang dipimpin oleh Sultān yang arif, bijaksana, dan ber-akhlāq alkarīmah, Raden Fatah. Rakyat, pada saat itu, hidup dalam kemakmuran, kesejahteraan, dan ketentraman, karena pola pemerintahan yang diterapkan berazaskan musyawah dan kerja sama yang harmonis antar 'ulamā' (para wali) dan umarā'. Kerajaan Demak mengalami kemajuan yang saangat pesat dan disegani (Nyatnyono 2014).

Keberhasilan yang telah dicapai oleh kerajaan Demak tersebut, tidak lepas dari peran seorang 'ulamā' /Waliyullāh yang berpangkat Tumenggung. Beliau adalah Waliyullāh Hasan Munadi. Beliaulah yang memimpin tentara Kerajaan Demak dalam melawan kejahatan dan keangkuhan yang ingin mengacaukan dan memperlemah kerajaan. Beliau merupakan figur pemimpin yang pemberani, bijaksana, berwibawa, dan kuat (sakti). Akan tetapi, Beliau tidak selamanya menetap di kerajaan, bahkan pangkat Tumenggung yang beliau sandang ditinggalkannya (Nyatnyono 2014).

Kebesaran, kemegahan, dan kemewahan yang Beliau lepaskan, didasarkan oleh keadaan di luar kerajaan yang masih harus diperjuangkan, termasuk daerah sebelah selatan Kerajaan Demak. Di sana, rakyatnya masih banyak yang hidup dalam kegelapan (tidak beriman), mereka belum mendapatkan cahaya kebenaran dari Allāh SWT. Mereka masih kebingungan dalam memilih tata cara yang baik untuk beribadah kepada Sang Maha Pencipta. Kebanyakan dari mereka masih menyembah batu, pohon, hantu, syaịtān, dan lain-lain. Pada saat itulah Waliyullāh Hasan Munadi bertekad menyampaikan ajaran yang haq dari Allāh SWT. Dengan sifat arif, bijaksana, berbudi luhur, penuh kasih sayang, dan tidak membeda-bedakan kasta, Beliu meninggalkan kerajaan menuju ke arah Selatan Kerajaan Demak (Nyatnyono 2014).

Di dalam perjalanannya, Beliau berusaha mendekati dan mengajak rakyat kecil untuk beriman dan beribadah kepada Allāh SWT. Diantara para pengikut Beliau yang setia dan menjadi santrinya adalah Kyai Gede Cendono. Ia masih keturunan dari Pembesar Kerajaan Majapahit dan Ki Ageng Sakiringan yang makamnya berada di Desa Nyatnyono. Waliyullāh Hạan Munadi telah banyak menanamkan bibit-bibit 
muballig dan santri di saat melakukan perjalanan dakwahnya. Kemudian Beliau menuju ke Gunung Suralaya untuk berkhalwat (bertapa istilah jawa) memohon kepada Allāh agar dalam perjuangannya bisa sukses, mengingat pihak-pihak yang akan dihadapinya merupakan tokohtokoh sakti dan kuat, diantaranya yaitu: Ki Ajar Bontit dan Raden Potro Kusumo (Nyatnyono 2014).

Setelah kira-kira seratus hari Beliau berkhalwat di Gunung Suralaya, saat akan meninggalkan tempatnya, terlintas sebuah gambaran masjid (ada yang mengatakan kayu yang berlubang calon bedug). Yang kemudian dari peristiwa itu Beliau dikatakan dalam istilah jawa: "lagi menyat wis ana", artinya baru bangun sudah ada, yang kemudian menjadi nama "Nyatnyono" (Nyatnyono 2014).

Akhirnya, Beliau menetap di tempat tersebut untuk membangun Masjid. Akan tetapi, pada saat yang sama, pembangunan Masjid Demak juga akan dimulai. Karena pada saat itu beliau didatangi oleh Kanjeng Sunan Kalijaga untuk diminta bantuannya dalam membangun masjid di Demak. Waliyullāh Ḥasan Munadi berkata: "Kanjeng Sunan di sini juga sudah terdapat lakaran/gambaran masjid yang harus segera dibangun (Masjid Nyatnyono)". Dari sini diketahui bahwa kisah pembangunan masjid Nyatnyono lebih awal dari pembangunan masjid Demak (Kisah Sunan/Kalijaga), (Nyatnyono 2014).

Masjid Nyatnyono pertama kali dibuat hanya memakai satu tiang/ soko. Oleh Kyai Raden Purwo Hādi diubah menjadi 4 soko/tiang pada zaman Belanda setelah bertapa 1 (satu) tahun di masjid dan makam Nyatnyono (kisah trah Nyatnyono). Kemudian direhap yang ke III pada tahun 1985 oleh masyarakat dengan tidak mengubah tiang/soko sama sekali (Nyatnyono 2014).

Sejarah pembangunan Masjid Nyatnyono yang hanya memakai satu tiang/soko di atas, berkaitan dengan pengambilan satu tiang/soko Masjid Demak oleh Kanjeng Sunan kalijaga. Pengambilan satu tiang/ soko Masjid Demak oleh Sunan Kalijaga untuk dibawa ke Nyatnoyno menyebabkan tiang Masjid Demak menjadi kurang satu tiang. Akhirnya, kekurangan satu tiang/soko tersebut oleh Kanjeng Sunan Kalijaga dibuatkan dari tatal (potongan-potongan kayu kecil, bahasa jawa). 
Pembangunan Masjid Agung Demak akhirnya dapat terlaksana dengan baik (Nyatnyono 2014).

Karena itu, tidak mengherankan apabila Desa Nyatnyono ditetapkan sebagai salah satu destinasi wisata religi atau wisata ziyarah atau wisata keagamaan di Kota Semarang. Disebut pariwisata keagamaan karena bentuk pariwisata di Desa Nyatnyono sasaran kunjungannya adalah tempat-tempat suci agama, misalnya: Masjid Pondok Pesantren An-Nur dan ziyarah ke makam Waliyullāh Ḥasan Munadi dan Hasan Dipuro, Sendang Kalimah Ṭayyibah dan Sendang Amānah.

Adapun tujuan perjalanan yang dilakukan oleh para wisatawan wisata religi di Desa Nyatnyono adalah untuk melihat atau menyaksikan upacara-upacara keagamaan, seperti: kunjungan ke makam Waliyullāh Hasan Munadi dan Hasan Dipuro serta makam-makam raja atau tokohtokoh masyarakat yang dikeramatkan oleh masyarakat, mandi dan mengambil air di Sendang Kalimah Ṭayyibah dan Sendang Amanah.

Selain ziarah makam, Desa Nyatnyono juga memiliki beberapa budaya religi yang rutin dilakukan oleh masyarakatnya, antara lain yaitu: iriban, merti dusun, yasinan, nyadran (ruwahan), pengajian malam Selasa Kliwon, pengajian Nuzul al-Qur'an, syuronan, tirakatan, dan lain sebagainya. Budaya-budaya religi ini tidak hanya diikuti oleh masyarakat yang bertempat tinggal di Desa Nyatnyono saja, tetapi juga diikuti oleh masyarakat yang berasal dari luar desa tersebut. Kegiatankegiatan budaya religi ini dikoordinir oleh aparatur desa beserta tokohtokoh masyarakat di Desa Nyatnyono dan dilaksanakan secara rutin setiap tahun.

\section{Sejarah Singkat Air Keramat Waliyullāh Ḥasan Munadi}

Diketahuinya air keramat Waliyullāh Hasan Munadi berawal dari rencana merehap Masjid peninggalannya yang kondisi bangunannya sangat memprihatinkan. Bila musim hujan tiba, maka masjid hampir tidak dapat digunakan untuk melaksankan șalāt dikarenakan bocor dan telalu tua bangunannya.

Membongkar dan merehap merupakan penyelematan Masjid peningggalan Waliyullāh Hạan Munadi tersebut. Jika dihitung dari 
segi perbaikan yang akan dilaksankan, maka merupakan yang ketiga kalinya setelah perbaikan pada zaman Belanda yang dilakukan oleh Kyai Raden Purwo Hādi. Rencana tersebut mulai dirintis pada tahun 1980, sementara air keramat pada waktu itu sudah ada tetapi alirannya masih sangat kecil tidak seperti yang kita lihat saat ini. Disamping itu masyarakat sekitarnya belum mengetahui manfaat air tersebut.

Adanya keinginan agar perbaiakan Masjid peninggalan Waliyullāh Hasan Munadi cepat terlaksana, perangkat desa mengutarakan niat tersebut pada Bapak Bupati Semarang untuk memberikan bantuan pada waktu acara Tarling (Tarwih Keliling) yang hadir pada acara tersebut. Akan tetapi keinginan tersebut tidak dikabulkan oleh Bapak Bupati Semarang. Ia mengatakan: "Masak perbaikan Masjid dimintakan bantuan, silahkan dibangun sediri agar tidak tergantung pada orang lain.” Akhirnya, perangkat desa bermusyawarah untuk membentuk panitia perbaikan masjid dan bersepakat memilih Imam Masjid sebagai ketua panitianya. Dengan terpilihnya Imam Masjid sebagai ketua maka mulai saat itu Imam Masjid dan panitia berusaha agar pembongkaran/ perbaikan masjid dapat terlaksana secepatnya.

Langkah pertama yang dilaksankan oleh Imam Masjid dan panitia adalah mengajak masyarakat bermujahadah lebih dahulu di makam Waliyullāh Hasan Munadi sebelum melakukan pembongkaran/ perehaban. Hal ini dilakukan karena masjid ini merupakan peninggalan dan dibangun pertama kali oleh Waliyullāh Ḥasan Munadi. Mujahadah juga dilakukan selama 100 hari di puncak Gunung Suralaya.

Langkah pertama di atas pada kenyataannya banyak menemui hambatan dari sebagian masyarakat. Mereka tidak setuju dengan langkah Imam Masjid. Mereka berkata: "Masak membongkar/merehab masjid dengan mujahadah." Sekalipun demikian, Imam Masjid dan panitia terus melakukan pendekatan dan bersilaturahim kepada para 'ulamä' untuk minta saran dan doa restu dalam rangka membongkar/merehab Masjid peninggalan Waliyullāh Hasan Munadi, karena menurut mereka, hanya 'ulamā' yang paling tahu tentang ihwal para wali. Diantara 'ulamā' yang dikunjungi adalah al-magfurlah KH. 'Abdul Hamīd Kajoran Magelang dan KH. Ahmad 'Abdul Ḥaq Watucongol Muntilan. Kedua 'ulamä' tersebut menyarankan agar dalam merehap Masjid jangan diminta 
mintakan, sebab itu Masjid peninggalan Waliyullāh Ḥasan Munadi yang sangat kaya, buktikan saja nanti masjid tersebut akan dibangun sendiri oleh Waliyullāh. Mendengar Fatwa kedua 'ulamā' tersebut panita bertambah bingung, darimana dananya padahal dana yang dimiliki dari masyarakat sangat sedikit. Kedua 'ulamā' tersebut dalam pesannya mengingatkan bahwa: "Jangan sekali-kali kamu ubah/kamu pindah lokasi masjid, bangun apa adanya saja."

Akhirnya dengan musyawarah yang disetujui panitia dan masyarakat secara bulat, pembongkaran dilaksanakan dengan mendatangkan dua 'ulamā' tersebut untuk memimpin tahlīl dimakam Waliyullāh Hasan Munadi sebelum pembongkaran dimulai. Berkat do'a dua 'ulamā’ tersebut pembongkaran berjalan lancar tanpa adanya rintangan dan hambatan. Demikian juga masyarakat dengan giat bersama-sama membangun kembali setiap hari. Akan tetapi, setelah lima belas hari pembogkaran dilakukan, masyarakat Desa Nyatnyono dikagetkan dengan banyaknya para tamu yang ikut membantu berasal dari sebelah kiri/utara makam, bahkan semakin hari semakin bertambah banyak.

Masyarakat menjadi bingung dengan kejadian tersebut. Akhirnya, panitia memutuskan untuk berkunjung (sowan) kembali kepada dua 'ulamā' tadi untuk menanyakan kejadian tersebut. Kedua 'ulamā' tersebut menegaskan bahwa: "Air sebelah kiri/utara makam merupakan sebagian kecil karomah Waliyullāh Hasan Munadi yang diperlihatkan karena masjidnya dibangun. Dari tempat itulah dana untuk masjid akan terkumpul, dan masjid kalian akan bergambar uang. Pasang saja kotak amal agar bagi tamu yang datang dapat memasukkan amal jariyahnya pada kotak tersebut." Dan benar, kata-kata kedua 'ulamā' tersebut terbukti. Semakin hari tamu yang datang semakin banyak, dana yang terkumpul juga semakin bertambah banyak. Sedemikian banyaknya pengunjung, sehingga tidak dapat dibedakan antara siang dan malam. Akhirnya pembongkaran/perbaikan Masjid dapat diselesaikan dengan baik. Selanjutnya juga dilakukan perbaikan makam Waliyullāh Hasan Munadi dan jalan raya, mulai dari bawah hingga sampai Desa Nyatnyono, dan dibangun juga madrasah, pondok pesantren, musalla-musalla, dan bahkan dapat membantu pembangunan sejumlah pondok pesanteran diberbagai daerah (Nyatnyono 2014). 


\section{Budaya Religi}

Budaya dalam kamus bahasa Indonesia diartikan sebagai pikiran; adat istiadat; sesuatu yang sedang berkembang; sesuatu yang menjadi kebiasaan yang sukar diubah. Sedangkan menurut Tylor, dalam Wiranata $(2002,95)$ bahwa kebudayaan adalah keseluruhan yang kompleks, yang di dalamnya terkandung ilmu pengetahuan, kepercayaan, kesenian, moral, hukum, adat istiadat, dan kemampuan yang lain serta kebiasaan yang didapat oleh manusia sebagai anggota masyarakat. Dalam pandangan Geertz (2013), budaya merupakan pola sejarah yang mentransmisikan makna yang melekat dalam simbol-simbol yang digunakan oleh suatu masyarakat. Pada tataran ini budaya menjadi sebuah sistem konsepsi yang diwariskan dari satu generasi kepada generasi berikutnya dalam bentuk simbol-simbol sesuai dengan artinya. Simbol-simbol ini digunakan pada saat mereka berkomunikasi atau pada saat mereka melestarikan dan mengembangkan pengetahuan tentang kehidupan dan bagaimana mereka harus bersikap dalam kehidupan ini.

Menurut Linda Smireich dalam N. Jabnoun, Budaya adalah sistem nilai dan keyakinan bersama yang menghasilkan norma perilaku (Neceur Jobnoun 2008, 33). Budaya juga diartikan sebagai pola perilaku yang membentuk sebagai hasil cipta manusia yang dipakai secara turuntemurun berupa nilai-nilai khusus yang melekat untuk mencapai tujuan hidup manusia yang dapat berupa simbol-simbol, pola perilaku dan pengetahuan. Kotter dan Heskett menulis bahwa budaya adalah kualitas setiap kelompok manusia tertentu yang diwariskan dari satu generasi ke generasi berikutnya (J. P. Kotter and Heskett J.L 1992, 3). Keduanya juga mengutip makna budaya menurut American Heritage Dictionare, yaitu: "Keseluruhan pola perilaku sosial, seni, keyakinan, institusi, dan semua produk lain dari pekerjaan manusia dan karakteristik pemikiran dari suatu komunitas atau populasi."

Budaya religi (religious culture) dalam konteks penelitian ini adalah pembudayaan nilai-nilai Islām di masyarakat, dimana kebudayaan ini disesuaikan dengan agama yang dianut hampir sebagian besar masyarakat. Pada prinsipnya, masyarakat Indonesia adalah masyarakat religius yaitu masyarakat yang memiliki kesadaran beragama. Hampir seluruh masyarakat ndonesia meyakini adanya Tuhan yang 
Maha Esa yang menciptakan manusia dan alam semesta. Dalam memperkuat keyakinan ini, masyarakat memiliki cara yang berbeda dalam mengekspresikannya, salah satunya adalah melalui kebudayaan. Religius menurut Asmaun Sahlan adalah nilai-nilai kehidupan yang mencerminkan tumbuhkembangnya kehidupan beragama yang terdiri dari tiga unsur pokok yaitu: 'aqīdah, ibadah, dan akhlak yang menjadi pedoman perilaku sesuai dengan aturan-aturan Ilahi untuk mencapai kesejahteraan serta kebahagiaan hidup di dunia dan akhirat (Asmaun Sahlan 2012, 69).

Konsep religi mengandung berbagai unsur seperti keyakinan, ritual, upacara, sikap dan pola tingkah laku, serta alam pikiran dan perasaan para penganutnya. Berbagai aktifitas seperti berdo'a, bersujud, bersaji, berkorban, slametan, makan bersama, menari dan menyanyi, berprosesi, berseni drama suci, berpuasa, bertapa, bersemedi, mengucapkan mantra, mempraktikkan magis, mempercayai makhluk-makhluk halus (gaib), menyediakan sesajen dan lain sebagainya, merupakan bagian dari aktifitas religi (Koentjaraningrat 1963, 81). Aktifitas inilah yang membuat sebuah kepercayaan menjadi suatu religi.

\section{Budaya Religi dan Kearifan Lokal}

Kearifan lokal adalah perilaku positif manusia ketika berinteraksi dengan alam dan lingkungan lokalnya yang berasal dari nilai adat religius mereka, nasihat nenek moyang atau budaya lokal, yang secara alami dibangun di dalam komunitas untuk beradaptasi dengan lingkungan lokalnya (Vitasurya 2016, 99). Sedangkan definisi lain dari kearifan lokal adalah upaya masyarakat untuk melestarikan sumber daya yang dapat digunakan terus menerus untuk memberi makan masyarakat dan menjaga keseimbangan lingkungan (Suryo Sakti Hadiwijoyo 2012). Secara konseptual, kearifan lokal merupakan bagian dari kebudayaan.

Kearifan lokal pada hekekatnya adalah pengetahuan dasar yang diperoleh dari hidup secara seimbang dengan alam. Hal ini terkait dengan budaya di masyarakat yang terakumulasi dan diwariskan. Kebijaksanaan ini dapat bersifat abstrak dan konkrit, tetapi karakteristik yang penting adalah bahwa ia berasal dari pengalaman atau kebenaran yang diperoleh dari kehidupan. Kebijaksanaan dari pengalaman nyata 
mengintegrasikan tubuh, semangat, dan lingkungan. Ini menekankan rasa hormat masyarakat kepada sesepuh atau leluhur dan pengalaman hidup mereka (Sopa 2018, 524), sebagaimana terlihat pada budaya religi di Desa Nyatnyono.

Keyakinan terhadap Tuhan Yang Maha Esa serta kebudayaan yang diwariskan dari generasi ke generasi memunculkan budaya religi yang menjadi bagian dari kearifan lokal suatu daerah. Budaya religi tersebut merupakan bentuk penghormatan kepada Tuhan Yang Maha Esa dan para leluhur-leluhur yang menjadi panutan secara turun-menurun sehingga menjadi jati diri dari masyarakat tersebut.

Ada dua pandangan besar mengenai hubungan antara kebudayaan dengan religi. Pandangan pertama adalah yang menyatakan bahwa kebudayaan merupakan bagian dari religi; sedangkan pandangan kedua menyatakan religi adalah bagian dari kebudayaan. Pandangan pertama, tidak bisa dipahami oleh mereka yang berusaha menjelaskan segala fenomena yang menyangkut hidup manusia secara kognitif. Sebaliknya pandangan kedua adalah tidak akseptabel bagi mereka yang percaya bahwa hidup manusia adalah realisasi dari wahyu yang tidak mensyaratkan pengertian (Budiono Kusumohamidjojo 2010, 219).

Kebudayaan dan agama dalam pandangan Geertz (2013)adalah agama sebagai sistem kebudayaan. Dalam pandangannya kebudayaan sebagai pola kelakuan yang terdiri dari serangkaian aturan-aturan, pedoman-pedoman, petunjuk-petunjuk yang digunakan manusia untuk mengatur tingkah lakunya. Dengan demikian, kebudayaan dapat diartikan dari pengorganisasian pengertian-pengertian yang tersimpul dalam simbol-simbol yang berkaitan dengan ekspresi manusia. Karena itu Geertz (2013) kemudian memahami agama tidak saja sebagai seperangkat nilai di luar manusia tetapi juga merupakan sistem pengetahuan dan sistem simbol yang memungkinkan terjadinya pemaknaan. Dimana pada umumnya kebudayaan yang berlandaskan agama adalah pemaknaan atau ekspresi dari manusia dalam keyakinannya terhadap Tuhan Yang Maha Esa.

Terkait penyebutan agama dan religi, ada dua cara pandang dari Harsojo (ahli antropologi). Pertama, ia lebih suka menggunakan istilah 'religi' ketimbang 'agama', karena istilah 'agama' menurutnya 
sudah memiliki arti tertentu yang spesifik seperti 'agama Islām atau agama Nasrani. Harsojo juga lebih suka menggunakan istilah 'religion' ketimbang 'confession' sebagai istilah yang hendak merangkum sistem kepercayaan manusia sebagai suatu fenomena umum. Kedua, ia menjelaskan bahwa antropologi menyelidiki religi secara empiris dan komparatif untuk memahami asal-usul religi, fungsi religi, dan sistematika religi. Antropologi tidak menyelidiki kebenaran dalam religi, melainkan menyelidiki pengaruh agama itu pada manusia dan masyarakat serta pengaruhnya pada perkembangan kebudayaan. Religi merupakan bagian dari kebudayaan manusia, oleh karenanya kedua pendekatan itu (teologi dan antropologi) tidak perlu saling bertentangan (Harsojo 1984, 220-21).

\section{Praktik Budaya Religi di Desa Nyatnyono}

Berdasarkan pada sejarah munculnya nama Nyatnyono yang berawal dari keinginan Waliyullāh Hasan Munadi menyebarkan agama Islām di kampung halamannya, tidaklah mengherankan jika budaya-budaya religi yang dilakukan adalah budaya yang berlandaskan pada nilai-nilai keIslām-an. Budaya religi yang sudah diadopsi menjadi kearifan lokal bagi masyarakat Desa Nyatnyono adalah sebagai berikut:

\section{Iriban}

Iriban merupakan suatu kegiatan peminjaman uang atau barang kepada anggota yang membutuhkan yang kelak akan dikembalikan pada saat anggota lainnya membutuhkan barang tersebut yang dilaksanakan secara bergantian dari rumah ke rumah berdasarkan hasil undian (Purnomo, Irawati, and Melati 2010, 62). Kegiatan Iriban telah menjadi tradisi dan kegiatan berupa arisan dimana jumlah uang yang disetor harus sama bagi semua anggota. Iriban juga berarti kegiatan mengumpulkan uang atau barang yang bernilai sama oleh beberapa orang kemudian diundi di antara mereka untuk menentukan siapa yang memperolehnya, undian dilaksanakan di sebuah pertemuan secara berkala sampai semua anggota memperolehnya (www.kompasiana.com). Iriban yang dilaksanakan oleh masyarakat Desa Nyatnyono dikoordinir oleh Badan Usaha Milik Desa (BUMDES), dimana secara rutin petugas 
dari BUMDES akan mengkoordinir peserta iriban. Untuk peserta iriban, tidak semua masyarakat mengikutinya, biasanya khusus pengelola serta pengusaha di area wisata. Hasil iriban ini akan dimasukkan ke dalam kas desa, yang nanti akan dipinjamkan ke sesama anggota peserta iriban jika dibutuhkan ataupun akan dikelola kembali untuk penunjang fasilitas di sekitar area wisata.

\section{Merti Dusun}

Kegiatan Merti Dusun diawali dengan upacara serah terima $u b o$ rampe ritual. Dalam upacara ini masyarakat menyajikan ubo rampe yang dikumpulkan menjadi satu untuk diserahkan kepada Kepala Dusun. Kepala Dusun menyerahkan ke pimpinan ritual untuk disajikan dalam acara Merti Dusun. Setelah penyerahan uba rampe, diadakan doa bersama. Dalam doa bersama ini, masyarakat di Desa Nyatnyono berkumpul bersama untuk berdoa yang dipimpin oleh pimpinan ritual, atas keselamatan dan rejeki yang telah diberikan kepada masyarakat di tahun tersebut. Setelah doa selesai dilakukan, kemudian masyarakat dipersilahkan untuk mengambil ubo rampe tersebut. Ubo rampe menjadi rebutan tidak hanya oleh masyarakat Desa Nyatnyono, tetapi juga oleh pengunjung dari luar desa. Ada kepercayaan di masyarakat bahwa ubo rampe tersebut mengandung berkah.

Kegiatan Merti Dusun ini diadakan karena sudah menjadi suatu tradisi dan naluri masyarakat Desa Nyatnyono. Tujuan diadakannya acara ini adalah sebagai suatu ucapan rasa syukur terhadap Tuhan Yang Maha Esa atas segala limpahan rejeki di tahun ini dan tahuntahun berikutnya.

\section{Yasinan}

Yasinan adalah membaca surah yasin secara bersama-sama untuk mengenang meninggalnya seseorang yang bertujuan untuk mendo'akan agar almarhūm atau almarhūmah mendapatkan ampunan dan rahmat dari Allāh SWT. Kegiatan ini dilaksanakan setiap malam Selasa Kliwon dimana tujuan dari yasinan ini adalah untuk berdoa meminta kebaikan bagi Waliyyullāh Ḥasan Munadi dan kyai Ḥasan Dipuro, serta meminta keselamat bagi seluruh masyarakat Desa Nyatnyono. 


\section{Nyadran (Ruwahan)}

Sadranan atau nyadran, menurut Slamet Muljana (2007: 44) berasal dari bahasa Jawa Kawi çraddha (srada), yang kemudian dijawakan modern nyadran (yang benar semestinya nyradan). Jika merujuk kamus bahasa Jawa kuna (P.J. Zoetmulder \& S.O. Robson, 2006: 1118-9), istilah Srada terdiri atas dua pengertian. Pertama, śraddhā, śrěddha, śrěddhah dari bahasa Sanskerta yang berarti kepercayaan, keyakinan, kesetiaan, harapan, keinginan. Juga bermakna kemurahan hati dan penerimaan dengan ramah. Tentu jika ini yang dikaitkan dengan ritual tradisi nyadran masih kurang cocok konteksnya, walaupun dalam upacara nyadran tersebut memang terdapat keyakinan dan kepercayaan tertentu yang mendasarinya. Kedua, śraddha yang berarti upacara untuk menghormati dan untuk memberi manfaat anggota keluarga yang telah wafat. Pengertian inilah yang dikemukakan oleh sumber Kitab Nägara Kerrtāgama (63.2; 67.1) dan Sārasamuccaya (286.3). Nampaknya "sadran" merupakan ungkapan dari bahasa śraddha ini, yang seharusnya adalah "sraddan", namun mengalami "kelimurologi" menjadi "saddran" (I Ketut Riana 2009, 310).

Sadranan secara umum merupakan bentuk ritual melalui doa dan sedekahan (uba rampe makanan), yang dimaksudkan untuk mendoakan arwah atau orang-orang yang sudah meninggal. Bulan pelaksanaan bervariasi antara daerah satu dengan yang lain. Ada yang melakukannya di bulan Muharram (Syuro), Safar, dan yang terbanyak dilakukan di bulan Sya'ban (Ruwah). Diharapkan dari proses itu, terjadi efek dari do'a dalam bentuk pengembalian energi, yang akan mengarah para pelakunya. Artinya dengan mendo'akan mereka yang sudah meninggal, maka yang melakukan do'a akan mendapatkan efek balik energi positif bagi kehidupannya, atau yang sering dikenal dengan sebutan "ngalap berkah" (Muhammad Sholikhin 2010, 167).

Acara inti Tradisi Nyadran di Desa Nyatnyono diawali dengan prosesi ziarah makam leluhur pendiri desa yaitu makam Waliyullāh $\mathrm{H}$ asan Munadi dan anaknya kyai Hasan Dipuro dengan berdoa kepada Tuhan Yang Maha Esa untuk memohon kebaikan bagi para pendiri Desa Nyatnyono. Ritual ini bagi masyarakat di desa Nyatnyono memainkan peran penting secara religius. Kepercayaan masyarakat 
terhadap kehadiran leluhur dan pengaruhnya pada kehidupan di Desa Nyatnyono masih dipegang teguh sampai saat ini. Tradisi nyadran juga banyak dijumpai di daerah Jawa. Di Jawa Tengah, misalnya di Kabupaten Sukoharjo terdapat Makam Ki Ageng Majastro yang rutin diselenggarakan ritual Nyadran ketika tanggal 1 Suro (Indrawati et al. 2016, 657). Di Jawa Timur terdapat masyarakat Samin yang memiliki adat yang disebut Sadranan yang biasanya diadakan setiap Senin Pon setelah pelaksanaan panen. Hal ini dilakukan untuk menumbuhkan rasa kebersamaan. Di Sadranan, warga mengunjungi setiap rumah dan kemudian disajikan dengan makanan tradisional yang terbuat dari hasil bahan mentah (Renny Oktafia and Mawardi 2017, 104).

\section{Peringatan Nuzul al-Qur'ān}

Pada bulan Ramaḍān, masyarakat Desa Nyatnyono mempunyai acara rutin yang selalu diselenggarakan di saat Nuzul al-Qur'ān (sekitar tanggal 21 di bulan Ramaḍān), dimana acara tersebut berupa pengajian yang diikuti tidak hanya oleh masyarakat Desa Nyatnyono, tetapi diikuti juga oleh masyarakat dari luar desa tersebut, dan bahkan dari luar Kota Semarang. Prosesi pengajian tersebut dimulai dengan salāt Isyā’ dan Tarāwịh bersama, setelah itu dilanjutkan dengan ceramah dari kyai yang secara khusus diundang untuk memberikan nasihat serta pesan positif kepada masyarakat. Setelah șalāt Tarāwīh dilanjutkan makan bersama atau yang disebut dengan "Tradisi Ambengan".

Sebelum dimulainya Tradisi Ambengan, masyarakat Desa Nyatnyono terlebih dahulu menyiapkan nasi ambengan di atas alas dari bambu. Nasi ambengan tersebut akan didoakan terlebih dengan maksud agar masyarakat desa Nyanyono dikaruniai rejeki, kesehatan dan keselamatan. Setelah didoakan, nasi ambengan yang telah digelar di alas bambu dan dilengkapi dengan berbagai macam lauk pauk ini akan di makan secara bersama-sama. Makna dari makan bersama ini adalah bentuk ikatan persaudaraan antara sesama manusia dan sebagai wujud dari rasa syukur kepada Allāh SWT. 


\section{Syuronan}

Pelaksanaan syuronan dilakukan pada malam menyambut 1 (satu) Syuro yang diikuti oleh seluruh masyarakat Desa Nyatnyono. Acara syuronan dimulai dengan tahlilan dan do'a serta tirakat bersama. Dalam acara ini dipanjatkan do'a untuk meminta keselamatan serta keberkahan bagi masyarakat Desa Nyatnyono di tahun baru Islām yang akan datang.

\section{Kesimpulan}

Kehidupan masyarakat Desa Nyatnyono sarat dengan budaya religi yang merupakan kearifan lokal daerah tersebut. Kearifan lokal ini dapat dilihat pada budaya religi yang secara rutin diselenggarakan di Desa Nyatnyono berdasarkan nilai-nilai positif dalam kerangka mengekspresikan keyakinan kepada Tuhan Yang Maha Esa. Sejarah kelahiran Desa Nyatnyono berawal dari keinginan Waliyullāh Hasan Munadi untuk menyebarkan agama Islām di kampung halamannya. Dalam perjalanan dakwahnya, Waliyullāh Hasan Munadi membawa ajaran dan praktik-praktik keagamaan kepada masyarakat, yang pada proses selanjutnya menjadi "budaya religi" di Desa Nyatnyono. Budaya religi tersebut secara turun menurun di jaga dan dilaksanakan oleh keluarga penerus Waliyullāh Hasan Munadi beserta masyarakat di desa Nyatnyono. Selain berfungsi untuk mengagungkan Tuhan Yang Maha Esa, budaya religi yang dilakukan oleh masyarakat Desa Nyatnyono juga merupakan bentuk dari fungsi-fungsi sosial yang dapat merekatkan nilai solidaritas antar anggota masyarakat. 


\section{DATAR PUSTAKA}

Asmaun Sahlan. 2012. Religiusitas Perguruan Tinggi: Potret Pengembangan Tradisi Keagamaan Di Perguruan Tinggi Islām. Malang: UIN Maliki Press.

Budiono Kusumohamidjojo. 2010. Filsafat Kebudayaan. Proses Realisasi Manusia. Yogyakarta: Jalasutra.

Clifford Geertz. 2013. Agama Jawa: Abangan, Santri, Priyayi Dalam Kebudayaan Jawa. Depok: Komunitas Bambu.

Deni Adi Wijaya, Djono, and Suryo Ediyono. 2018. "Local Knowledge in Joglo Majapahit: Analysis of Local Wisdom Models Gemah Ripah Loh Jinawi in Rural Java." International Journal of Multicultural and Multireligious Understanding (IJMMU) 5(3): 113-22.

Endraswara, Suwardi. 2003. Metode Penelitian Kebudayaan. Yogyakarta: Gadjah Mada University Press.

Hariyanto, Oda Ignatius Besar. 2016. "DESTINASI WISATA BUDAYA DAN RELIGI DI CIREBON.” Jurnal Ecodemica: Jurnal Ekonomi, Manajemen, dan Bisnis 4(2): 214-22. https://ejournal.bsi.ac.id/ ejurnal/index.php/ecodemica/article/view/830 (July 11, 2019).

Harsojo. 1984. Pengantar Antropologi. Jakarta: Binacipta.

I Ketut Riana. 2009. Nagara Krtagama Masa Keemasan Majapahit. Jakarta: Kompas.

Indrawati et al. 2016. "Edu - Religious Tourism Based on Islamic Architecture Approach, a Prelimenary Research in Majasto Cemetery - Sukoharjo Regency Central Java." Procedia - Social and Behavioral Sciences 227: 656-63.

J. P. Kotter, and Heskett J.L. 1992. Corporate Culture and Performance. New York: The Free Press.

Koentjaraningrat. 1963. "Review: The Religion of Java, Clifford Geertz." Majalah Ilmu-Ilmu Sastra Indonesia.

Maula, Bani Syarif. 2016. “Indonesian Muslim Women: Between Culture, Religion, and Politics.” Ijtimā'iyya: Journal of Muslim Society Research 1(1): 113-31. http://ejournal.iainpurwokerto.ac.id/index.php/ ijtimaiyya/article/view/930 (July 11, 2019). 
Muhammad Ali. 2011. "Muslim Diversity: Islām and Local Tradition in Java and Sulawesi, Indonesia." IJIMS: Indonesian Journal of Islām and Muslim Societies 1(1): 1-35.

Muhammad Sholikhin. 2010. Ritual Dan Tradisi Islam Jawa. Yogyakarta: NARASI (Anggota IKAPI).

Neceur Jobnoun. 2008. Islām and Management. Riyāḍ: Internasional Islām ic Publishing House.

Nyatnyono, Desa. 2014. “Sejarah Desa Nyatnyono.” http://nyatnyono. desa.id/index.php/first/artikel/57.

Purnomo, Herry, Rika Harini Irawati, and Melati. 2010. Menunggang Badai - Untaian Kehidupan, Tradisi Dan Kreasi Aktor Mebel Jepara. Bogor: CIFOR.

Renny Oktafia, and Imron Mawardi. 2017. "Islāmic Values In The Tradition Of Samin Community In East Java." QIJIS: Qudus International Journal of Islämic Studies 5(1).

Rini Fidiyani, and Baidhowi. 2015. "Legal Development Bsed on Local Wisdom As The Basis of a Setting For Religious Life in Central Java." Jurnal Dinamika Hukum 15(3): 278-86. http://dinamikahukum.fh.unsoed. ac.id/index.php/JDH/article/view/478/403 (July 11, 2019).

Sopa, M. 2018. "Local Wisdom in the Cultural Symbol of Indonesian Traditional House." KnE Social Sciences 3(4): 524. https:// knepublishing.com/index.php/Kne-Social/article/view/1962 (July 11, 2019).

Suryo Sakti Hadiwijoyo. 2012. Perencanaan Pariwisata Perdesaan Berbasis Masyarakat (Sebuah Pendekatan Konsep). Yogyakarta: Graha Ilmu Publisher.

Vitasurya, Vincentia Reni. 2016. “Local Wisdom for Sustainable Development of Rural Tourism, Case on Kalibiru and Lopati Village, Province of Daerah Istimewa Yogyakarta." Procedia - Social and Behavioral Sciences 216: 97-108. https://www.sciencedirect. com/science/article/pii/S1877042815061947 (July 11, 2019).

Wiranata, I Gede A. B. 2002. Antropologi Budaya. Bandung: Citra Aditya Bakti. 